\title{
The Effect of Lowering the $\mathrm{pH}$ on the Composition and Metabolism of a Community of Nine Oral Bacteria Grown in a Chemostat
}

\author{
By ANN S. MCDERMID, $†$ AILSA S. MCKEE, $\dagger$ D. C. ELLWOOD ANd \\ P. D. MARSH*十 \\ Pathogenic Microbes Research Laboratory, PHLS Centre for Applied Microbiology and \\ Research, Porton Down, Salisbury, SP4 0JG, UK
}

(Received 9 September 1985 ; revised 29 November 1985)

\begin{abstract}
Nine oral bacteria, associated with both healthy and diseased sites in the mouth, were grown at $D=0.05 \mathrm{~h}^{-1}$ (mean generation time $13.9 \mathrm{~h}$ ) in a glucose-limited chemostat. After an initial period of steady-state growth at $\mathrm{pH} 7 \cdot 0, \mathrm{pH}$ control was discontinued. The $\mathrm{pH}$ then decreased until it stabilized at $\mathrm{pH} 4 \cdot 1$ after $9 \mathrm{~d}$ (16 generations), while the $E_{\mathrm{h}}$ rose from $-165 \mathrm{mV}$ to $+160 \mathrm{mV}$. The lowering in $\mathrm{pH}$ resulted in the composition and metabolism of the flora being altered and in increased bacterial aggregation. At $\mathrm{pH} 7 \cdot 0$, 'Streptococcus mitior', Veillonella alcalescens and $S$. sanguis were most numerous while at $\mathrm{pH} 4 \cdot 1$ the counts of all bacteria fell except for Lactobacillus casei, which became predominant. The proportions of $S$. mutans within the community also increased while $S$. sanguis was recovered only occasionally and Bacteroides intermedius was not detected below $\mathrm{pH} 4 \cdot 6$. The survival at $\mathrm{pH} 4 \cdot 1$ of several other species would not have been predicted from earlier pure culture studies. Relative to $\mathrm{pH} 7 \cdot 0$, the community growing at $\mathrm{pH} 4.1$ produced more lactic acid, washed cells had a greater glycolytic activity over a wider $\mathrm{pH}$ range but amino acid metabolism decreased. In general, when $\mathrm{pH}$ control was restored, so were the original patterns of metabolism and bacterial counts, except for $B$. intermedius, which was still not detected. The inverse relationship between $S$. sanguis and $S$. mutans, and the increase in proportions of $L$. case $i$ and $S$. mutans during growth in a low $\mathrm{pH}$ environment parallel observations made in vivo and suggest that the chemostat can be used as a model for microbial behaviour in dental plaque.
\end{abstract}

\section{INTRODUCTION}

Dental plaque is the complex microbial community found on the tooth surface embedded in a matrix of polymers of bacterial and salivary origin. It can be found on healthy enamel surfaces but is also implicated in the aetiology of two of the most prevalent diseases affecting industrialized societies: caries and periodontal disease. The transition of the oral flora from a commensal to a pathogenic relationship with the host is associated with a change in the metabolism and composition of the flora at specific sites (for a review, see Marsh \& Martin, 1984). Owing to the complexity of the oral ecosystem, it has proved difficult to identify the ecological factors responsible for such changes. Consequently, a number of in vitro models have been developed of which the chemostat is of particular value (van der Hoeven \& de Jong, 1984). This is because bacteria grow in plaque at sub-maximal rates (Beckers \& van der Hoeven, 1982) under a range of possible carbohydrate concentrations, nutrient limitations and $\mathrm{pH}$ values, all of which can be readily studied in isolation using conventional continuous culture techniques. Although the chemostat provides a homogeneous environment, complex communities of oral bacteria have been maintained for long periods under different environmental conditions when

\footnotetext{
+ Present address: Bacterial Metabolism Research Laboratory, PHLS Centre for Applied Microbiology and Research, Porton Down, Salisbury SP4 0JG, UK.
} 
plaque was used as the inoculum (Brown et al., 1978; Marsh et al., 1983). However, in order to compensate for the known variability in the composition of plaque taken from different sites or even from the same site at different times, recent chemostat studies have been standardized by the use of a defined inoculum of nine representative oral bacteria (McKee et al., 1985). In this latter study, the bacterial composition and metabolic activity of the communities were similar when grown under identical conditions in replicate experiments. Using the chemostat in this way it should be possible to observe simple cause-and-effect relationships after the alteration of a single variable. In the aetiology of dental caries, the growth and metabolism of bacteria at low external $\mathrm{pH}$ values are of prime importance. These low $\mathrm{pH}$ values occur regularly in plaque after the ingestion and metabolism of dietary sugars; for an example, see Schachtele \& Jensen (1982). Consequently, we have studied the effect of lowering the $\mathrm{pH}$ on the behaviour of a community of oral bacteria growing initially at $\mathrm{pH} 7 \cdot 0$.

\section{METHODS}

Bacterial strains. Nine organisms were chosen for their known importance and prevalence in dental plaque in both health and disease, and also for their relative ease of isolation and identification (McKee et al., 1985). The bacteria were Veillonella alcalescens ATCC 17745; Streptococcus mutans ATCC 27351 (a streptomycin-resistant strain); Streptococcus sanguis NCTC 7865; 'Streptococcus mitior' EF 186 (this strain does not produce extracellular polysaccharides from sucrose); Actinomyces viscosus WVU 627; Bacteroides intermedius (previously Bacteroides melaninogenicus subsp. intermedius) T588; Fusobacterium nucleatum ATCC 10953; Neisseria sp. A1076 and Lactobacillus casei AC 413. The non-culture-collection strains were human dental plaque isolates obtained from J. M. Hardie and H. N. Shah, Department of Oral Microbiology, The London Hospital Medical College, London E1 2AD.

Growth conditions. The chemostat was operated at a dilution rate $(D)$ of $0.05 \mathrm{~h}^{-1}$ (mean community generation time $13.9 \mathrm{~h}$ ), a temperature of $37^{\circ} \mathrm{C}$, a working volume of $600 \mathrm{ml}$, and under a gas phase of $5 \% \mathrm{CO}_{2}$ in $\mathrm{N}_{2}$. The pH was maintained initially at $7 \cdot 0 \pm 0 \cdot 1$ by the automatic addition of $2 \mathrm{M}-\mathrm{NaOH}$. The $E_{\mathrm{h}}$ was measured in situ with an autoclavable electrode; the standard used to calibrate the electrode was saturated quinhydrone (BDH) in $0.1 \mathrm{M}-$ $\mathrm{HCl}$ (Russell \& Coulter, 1975). The chemostat growth medium was a modification of BM medium (Shah et al., 1976), composition per litre distilled water: proteose peptone (Oxoid), $10 \mathrm{~g}$; trypticase peptone (BBL, Becton Dickinson), $5 \mathrm{~g}$; yeast extract (Difco), $5 \mathrm{~g}$; potassium chloride, $2.5 \mathrm{~g}$; cysteine hydrochloride (BDH), $0.5 \mathrm{~g}$; haemin (Sigma), $5 \mathrm{mg}$; vitamin $\mathrm{K}_{1}$ (Sigma), $1 \mathrm{mg}$. The medium was brought to the boil and sterilized by autoclaving at $121^{\circ} \mathrm{C}$ for $30 \mathrm{~min}$.

To achieve glucose limitation, this modified BM medium was supplemented with $28 \mathrm{mM}$-sterile glucose (McKee et al., 1985). After a period of steady-state growth at $\mathrm{pH} 7 \cdot 0$, the $\mathrm{pH}$ controller was switched off and the $\mathrm{pH}$ was allowed to stabilize. Once stabilized, and after a period of steady-state growth, $\mathrm{pH}$ control was restored and the $\mathrm{pH}$ was returned to and maintained at $7 \cdot 0 \pm 0 \cdot 1$. Ten pot volume changes of media (equivalent to 14 community generations) were allowed to elapse before a culture was deemed to have reached a steady state.

Chemostat inoculation. Each strain was grown anaerobically (except the Neisseria sp, which was grown aerobically) in batch culture to late exponential phase in BM medium containing $55.6 \mathrm{mM}$-glucose ( $V$. alcalescens was grown in BM medium containing $122.7 \mathrm{~mm}$-sodium lactate). From each culture $20 \mathrm{ml}$ was mixed and $90 \mathrm{ml}$ of this mixture inoculated into a chemostat. The purity of the inoculum was confirmed and viable counts made using a range of selective and non-selective media (McKee et al., 1985). Then $200 \mathrm{ml}$ culture medium was pumped into each chemostat to enable $\mathrm{pH}$ and temperature to be controlled and $D$ was adjusted to $0.05 \mathrm{~h}^{-1}$. A previous study had shown that not all of the nine bacteria are able to colonize after the first inoculation (McKee et al., 1985). Consequently, the chemostat was re-inoculated with all nine bacteria on two further occasions, 3 and $5 \mathrm{~d}$ after the first inoculation. Before each re-inoculation, a $100 \mathrm{ml}$ volume of culture was removed from each chemostat to accommodate the fresh $90 \mathrm{ml}$ inoculum and to ensure that the flow of medium was uninterrupted.

Viable counts of chemostat cultures. Viable counts of the microbial communities of each chemostat were made daily for at least the first 14 days, then thrice weekly until termination of the experiments. Samples were removed from the chemostats, dispersed, serially diluted in freshly-reduced BM medium and plated on a range of selective and non-selective media (McKee et al., 1985). All plates were incubated anaerobically for $6 \mathrm{~d}$ in an atmosphere of $10 \%(\mathrm{v} / \mathrm{v}) \mathrm{CO}_{2}, 20 \%(\mathrm{v} / \mathrm{v}) \mathrm{H}_{2}$ in $\mathrm{N}_{2}$, except for one set of vancomycin blood agar plates which were incubated aerobically for $3 \mathrm{~d}$ for the enumeration of Neisseria sp. Identification was assessed by colonial morphology, growth on selective media, Gram-staining reaction and on catalase production (McKee et al., 1985).

Washed cell experiments. Cells were collected during steady-state conditions via the chemostat overflow into a container cooled in ice, and were harvested by centrifugation $(8000 \mathrm{~g}$ for $10 \mathrm{~min})$. Cells were washed twice by centrifugation $(8000 \mathrm{~g}$ for $10 \mathrm{~min}$ ), resuspended in $200 \mathrm{mM}-\mathrm{KCl}$ to give approximately $30 \mathrm{mg}$ (dry weight) cells $\mathrm{ml}^{-1}$ and stored in ice until used. The washed cells were then diluted in $200 \mathrm{mM}-\mathrm{KCl}$ to give a final concentration of 
$5 \mathrm{mg}$ (dry weight) $\mathrm{ml}^{-1}$ in $5 \mathrm{ml}$. Acid production from storage material (endogenous metabolism) or after a pulse of excess ( $3 \mathrm{mM}$ ) glucose, sucrose, fructose or lactose was measured at $37^{\circ} \mathrm{C}$ under a constant flow of $\mathrm{O}_{2}-\mathrm{free}_{2} \mathrm{~N}_{2}$ in a $\mathrm{pH}$-stat (Radiometer) either as a $\mathrm{pH}$-fall from $\mathrm{pH} 7 \cdot 0$, in which the terminal $\mathrm{pH}$ was recorded after $15 \mathrm{~min}$, or as a glycolytic rate at a constant $\mathrm{pH}$ by the automatic titration of neutralizing alkali (100 mM-KOH) (Marsh et al., 1982). Units of glycolytic activity are expressed as nmol acid neutralized (mg dry weight cells) ${ }^{-1} \mathrm{~min}^{-1}$.

Analytical procedures. The $E_{\mathrm{h}}$, turbidity, dry weight and microscopic appearance of the cultures were determined regularly. During steady-state conditions the residual glucose, acid end products of metabolism and amino acid composition of culture filtrates were determined as described previously (Marsh et al., 1983).

\section{RESULTS}

Bacterial composition and metabolic properties of the microbial community growing initially at pH 7.0

After the chemostat had been inoculated on three separate occasions, all of the nine organisms present in the inoculum became established in the chemostat at $\mathrm{pH} 7.0$ although the proportions of individual populations varied markedly. The predominant species were ' $S$. mitior' and $V$. alcalescens while Neisseria sp. was present in only low numbers (Table 1). No residual glucose could be detected in culture filtrates (Table 2) and neither could arginine, cysteine, lysine and tryptophan (Table 3). In contrast, several other amino acids, and ornithine in particular, increased in concentration. Under steady-state conditions, the community of bacteria produced a mixed pattern of fermentation products with only low concentrations of lactic acid (Table 4), and the $E_{\mathrm{h}}$ of the culture remained relatively stable at approximately $-165 \mathrm{mV}$ (Fig. 1).

\section{Bacterial composition and metabolic properties of the microbial community growing at pH $4 \cdot 1$}

When $\mathrm{pH}$ control of the culture was stopped, the $\mathrm{pH}$ fell rapidly to 5.7 and within two community generations it had reached 4.8 . It finally stabilized at $\mathrm{pH} 4 \cdot 1$ nine $\mathrm{d}$ (16 community generations) after the $\mathrm{pH}$ controller was switched off; during this period, the $E_{\mathrm{h}}$ of the culture rose to approximately $+160 \mathrm{mV}$ (Fig. 1). Eight of the nine organisms survived the fall in $\mathrm{pH}$ and remained at relatively stable levels during growth at the lower $\mathrm{pH}$ (Table 1), although their ranking order with respect to one another and their viable counts changed. At $\mathrm{pH} 4 \cdot 1$, the predominant organisms under steady-state conditions were $L$. case $i, V$. alcalescens and $S$. mutans. Except for $L$. casei, the counts of all species fell and $S$. sanguis was recovered only twice (and in low numbers) (Fig. 1, Table 1); B. intermedius was not detected below pH 4.6. During steady-state conditions, residual glucose could be detected in culture filtrates (Table 2) and there was a reduced pattern of amino acid metabolism (Table 3 ). The pattern of fermentation products also changed and lactic acid was present in the highest concentrations (Table 4). The yield (dry weight) and total viable count of the community growing at $\mathrm{pH} 4.1$ were markedly lower than at $\mathrm{pH} 7.0$ (Table 2); bacterial aggregates could also be seen more commonly during growth at $\mathrm{pH} 4 \cdot 1$.

\section{Bacterial composition and metabolism of the bacterial communities when the $\mathrm{pH}$ was returned to pH 7.0}

When $\mathrm{pH}$ control was restored, the $E_{\mathrm{h}}$ fell as the $\mathrm{pH}$ returned immediately to neutrality (Fig. 1). There was a rapid increase in the numbers of several bacterial populations and, when steadystate conditions were attained, the viable counts and ranking order for many species were similar to their original values (Table 1). However, B. intermedius, which was lost from the culture when the $\mathrm{pH}$ fell, did not re-establish and counts of Neisseria sp., after an initial rise (Fig. 1), remained low. In contrast, $S$. sanguis, which persisted in barely detectable numbers at $\mathrm{pH} 4 \cdot 1$, was present at levels even higher than those obtained originally at $\mathrm{pH} 7.0$ (Table 1). This rise in $S$. sanguis was accompanied by a slight fall in the numbers of $S$. mutans compared to its original count at $\mathrm{pH} 7 \cdot 0$. The general patterns of fermentation products (Table 4), amino acid metabolism (Table 3) and glucose utilization (Table 2) together with the total viable count of the community were similar to those obtained originally at $\mathrm{pH} 7 \cdot 0$, although the yields were lower (Table 2). 

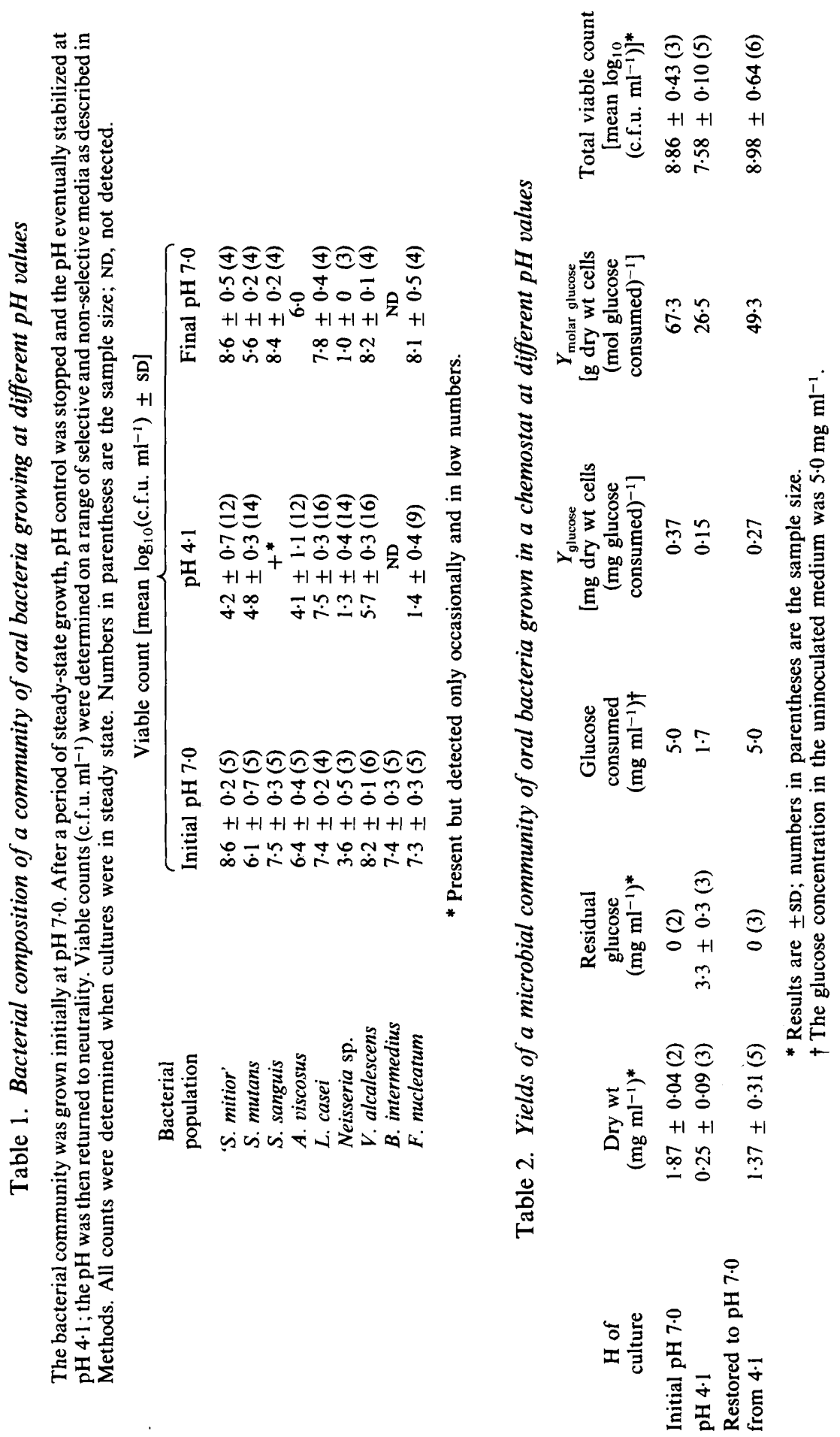
Table 3. Metabolism of amino acids during steady-state conditions in a chemostat by $a$ community of oral bacteria grown at different $\mathrm{pH}$ values

The metabolism is expressed as a percentage increase or decrease in the concentration of the amino acid in culture supernatants compared with the uninoculated medium. The results are the mean of at least duplicate samples taken from the chemostat on different days.

\begin{tabular}{|c|c|c|c|c|}
\hline \multirow[b]{2}{*}{ Amino acid } & \multirow{2}{*}{$\begin{array}{l}\text { Concn in } \\
\text { uninoculated } \\
\text { medium } \\
(\mathrm{mM})\end{array}$} & \multicolumn{3}{|c|}{$\begin{array}{l}\text { Percentage increase }(+) \text { or decrease }(-) \\
\text { in amino acid concn }\end{array}$} \\
\hline & & Initial $\mathrm{pH} 7.0$ & $\mathrm{pH} 4 \cdot 1$ & Final $\mathrm{pH} 7 \cdot 0$ \\
\hline Alanine & $2 \cdot 8$ & +200 & 0 & +100 \\
\hline 2-Aminobutyric acid & - & $t^{*}$ & $+^{*}$ & $+^{*}$ \\
\hline Arginine & $1 \cdot 7$ & -100 & -17 & -100 \\
\hline Aspartic acid & 1.9 & -80 & 0 & -64 \\
\hline Citrulline & - & $+^{*}$ & 0 & 0 \\
\hline Cysteine & $1 \cdot 1$ & -100 & -22 & -100 \\
\hline Glutamic acid & $2 \cdot 7$ & -97 & 0 & -96 \\
\hline Glycine & $2 \cdot 1$ & +200 & +5 & +116 \\
\hline Histidine & 1.9 & -88 & -30 & -93 \\
\hline Isoleucine & 1.6 & +71 & +17 & +100 \\
\hline Leucine & 3.6 & +25 & 0 & +25 \\
\hline Lysine & $2 \cdot 2$ & -100 & 0 & -100 \\
\hline Methionine & $1 \cdot 1$ & -90 & 0 & -70 \\
\hline Ornithine & $0 \cdot 1$ & +1000 & +567 & +1000 \\
\hline Phenylalanine & 1.7 & +53 & +14 & +30 \\
\hline Proline & $0 \cdot 3$ & +500 & 0 & +420 \\
\hline Serine & 1.8 & -91 & 0 & -84 \\
\hline Threonine & $1 \cdot 3$ & -42 & 0 & -50 \\
\hline Tryptophan & 0.3 & -100 & 0 & -100 \\
\hline Valine & $1 \cdot 6$ & +128 & 0 & +100 \\
\hline
\end{tabular}

* Detected in culture filtrates but not present in the uninoculated medium.

Table 4. Fermentation products produced during steady-state growth in a chemostat of a community of oral bacteria growing at different $\mathrm{pH}$ values

Numbers in parentheses are the sample size.

Fermentation
product

Ethanol

Acetic acid

Propionic acid

iso-Butyric acid

n-Butyric acid

iso-Valeric acid

Formic acid

Lactic acid

\begin{tabular}{|c|c|c|}
\hline \multicolumn{3}{|c|}{ Concn $(\mathrm{mM}) \pm \mathrm{SD}$} \\
\hline Initial $\mathrm{pH} 7 \cdot 0$ & $\mathrm{pH} 4 \cdot 1$ & Final $\mathrm{pH} 7 \cdot 0$ \\
\hline $16.5 \pm 3.2(2)$ & $17.3 \pm 8.7(5)$ & $20 \cdot 4 \pm 4 \cdot 3(3)$ \\
\hline $81.2 \pm 1.8(2)$ & $7 \cdot 3 \pm 4.9(6)$ & $\overline{89} \cdot 2$ \\
\hline $17 \cdot 3 \pm 0.2(2)$ & $0.3 \pm 0.2(6)$ & $22.9 \pm 6.3(3)$ \\
\hline $0(2)$ & $0.1 \pm 0.1(6)$ & $\overline{0}(3)$ \\
\hline $14.8 \pm 0.2(2)$ & $0.1 \pm 0.1(6)$ & $14.6 \pm 3.7(3)$ \\
\hline $0.3 \pm 0.3(2)$ & $0.1 \pm 0.1(6)$ & $0.2 \pm 0.2(3)$ \\
\hline $36.0 \pm 7.0(2)$ & $\overline{0}(5)$ & $36.1 \pm 0.1(2)$ \\
\hline $0.4 \pm 0.02(2)$ & $56.8 \pm 10.7(5)$ & $0.6 \pm 0.1(2)$ \\
\hline
\end{tabular}

Acid production by washed cells harvested from bacterial communities growing at pH 7.0 and

$$
\text { pH } 4 \cdot 1
$$

The community growing at $\mathrm{pH} 4.1$ had a higher level of endogenous metabolism of storage compounds and made more acid after a pulse of glucose, fructose or lactose than did the community growing at $\mathrm{pH} \mathrm{7.0,} \mathrm{either} \mathrm{before} \mathrm{or} \mathrm{after} \mathrm{the} \mathrm{pH}$ change (Table 5 ). The exception was with sucrose and this probably reflected the bacterial composition of the communities at the different $\mathrm{pH}$ values for the following reason. The strain of $L$. casei used in this study, and the predominant organism at $\mathrm{pH} 4 \cdot 1$ (Table 1), can not metabolize sucrose (Marsh et al., 1984). Acid from glucose was also made at a faster rate and over a wider $\mathrm{pH}$ range by the community grown 


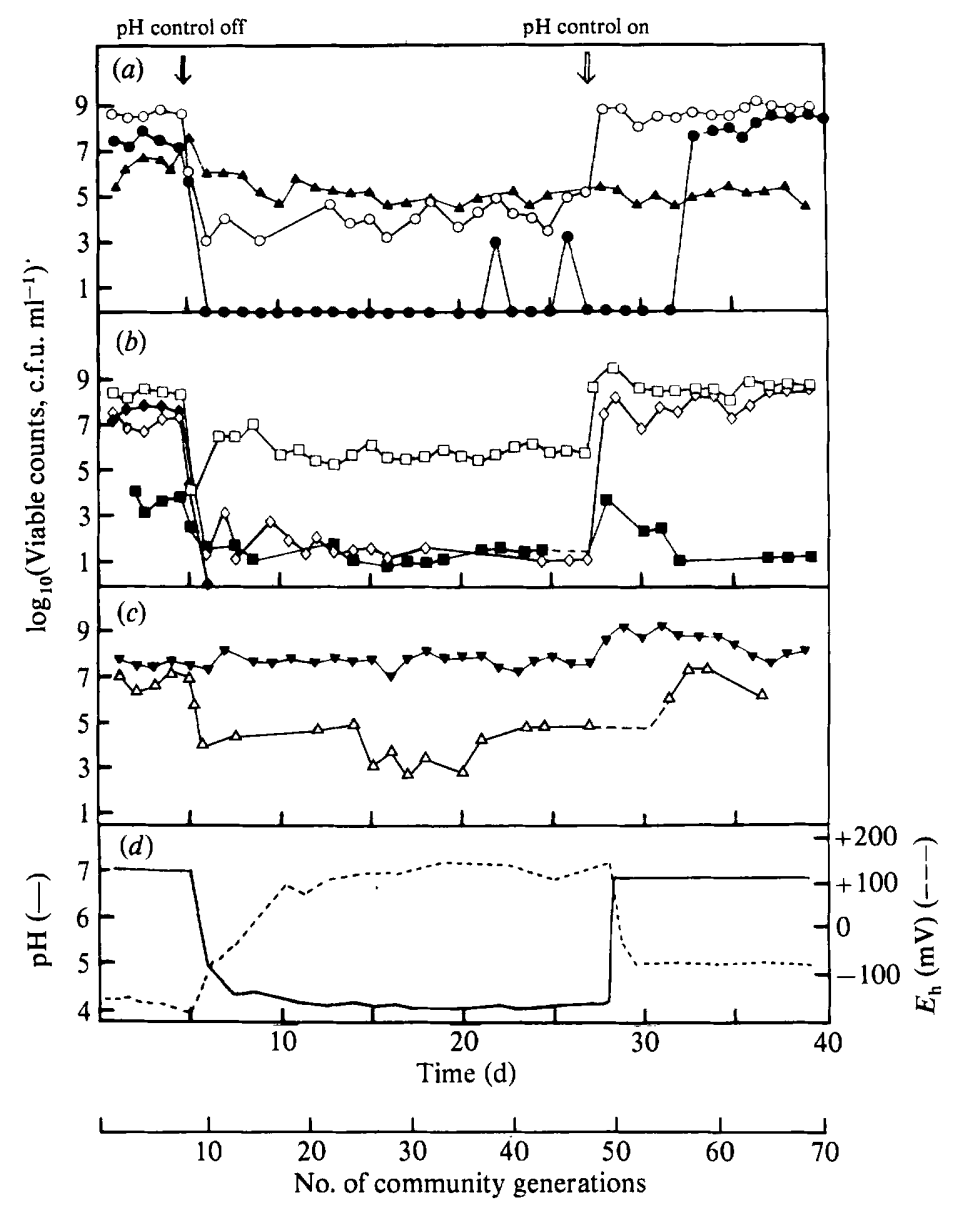

Fig. 1. Effect of $\mathrm{pH}$ on the $E_{\mathrm{h}}$ and bacterial composition of a community of nine oral bacteria growing in a chemostat. Viable counts [ $\log _{10}$ (c.f.u. $\left.\left.\mathrm{ml}^{-1}\right)\right]$ of $(a)$ 'S. mitior' $(O), S$. sanguis $(O)$ and $S$. mutans $(\boldsymbol{A})$; (b) Neisseria sp. ( $\square$ ), V. alcalescens $(\square), B$. intermedius $(\bullet)$ and $F$. nucleatum $(\diamond) ;(c) L$. casei $(\boldsymbol{\nabla})$ and $A$. viscosus $(\triangle)$. After a period of steady-state growth at $\mathrm{pH} 7 \cdot 0, \mathrm{pH}$ control was discontinued (filled arrow) and the $\mathrm{pH}$ was regulated by the metabolism of the flora $(d$, solid line). When the $\mathrm{pH}$ had stabilized and steady-state conditions had been reached, $\mathrm{pH}$ control was re-introduced (open arrow) and returned immediately to $\mathrm{pH} 7 \cdot 0$. The $E_{\mathrm{h}}$ of the culture was monitored throughout this period (d, dashed line).

at $\mathrm{pH} 4.1$ (Fig. 2). Its activity at $\mathrm{pH} 4.0$ was greater than that obtained at any $\mathrm{pH}$ value by the communities growing at $\mathrm{pH} \mathrm{7.0.} \mathrm{The} \mathrm{pH}$ optimum for acid production also shifted to a lower value compared to the communities grown at neutral $\mathrm{pH}$ (Fig. 2). Acid production by the community growing when the $\mathrm{pH}$ was returned to $7 \cdot 0$ was similar to the values obtained before the pH controller was switched off (Table 5, Fig. 2).

\section{DISCUSSION}

Ecological studies of microbial films such as dental plaque have been hindered because the repeated sampling of specific sites in man or animals, over short intervals, leads inevitably to the physical disruption of the sample area, which might, in itself, lead to a change in the bacteriological or biochemical profile of the flora. Consequently, a chemostat model has been developed whereby a representative community of oral bacteria can be grown reproducibly for long periods from a defined inoculum (McKee et al., 1985). The effect of varying single parameters on the behaviour of these communities can therefore be monitored regularly with ease. 


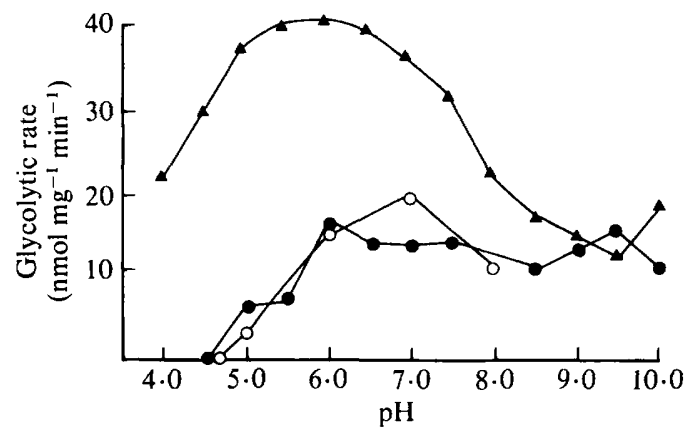

Fig. 2. Glycolytic rates of washed cells of a community of oral bacteria grown in a chemostat at different $\mathrm{pH}$ values. Cells were harvested from the chemostat and washed in $200 \mathrm{mM}-\mathrm{KCl}$, and glycolytic activity after a pulse of glucose was determined in a $\mathrm{pH}$-stat at different $\mathrm{pH}$ values. Glycolytic activity was measured as amount ( $\mathrm{nmol}$ ) of alkali required to neutralize metabolic acid ( $\mathrm{mg}$ dry weight cells) ${ }^{-1}$ Cells were harvested under steady-state conditions when the $\mathrm{pH}$ of the chemostat was initially at $\mathrm{pH} 7 \cdot 0$

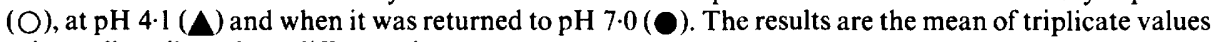
using cells collected on different days.

\section{Table 5. Acid production by harvested oral communities growing in a chemostat under steady-state conditions at different $\mathrm{pH}$ values}

Cells were harvested, washed and resuspended in $200 \mathrm{mM}-\mathrm{KCl}$ at $\mathrm{pH} \mathrm{7 \cdot 0}$. Acid production from endogenous metabolism of storage material or after a pulse of excess ( $3 \mathrm{~mm}$ ) glucose, sucrose, fructose or lactose was measured as the terminal $\mathrm{pH}$ after $15 \mathrm{~min}$. Numbers in parentheses are the number of estimations made on different days with freshly prepared cells.

\begin{tabular}{|c|c|c|c|}
\hline \multirow[b]{2}{*}{ Substrate } & \multicolumn{3}{|c|}{ Terminal $\mathrm{pH}$ after $15 \mathrm{~min} \pm \mathrm{SD}$} \\
\hline & Initial $\mathrm{pH} 7 \cdot 0$ & $\mathrm{pH} 4 \cdot 1$ & Final pH $7 \cdot 0$ \\
\hline Storage material & $6 \cdot 75 \pm 0.05(2)$ & $5.84 \pm 0.40(4)$ & $6.80 \pm 0.29(2)$ \\
\hline Glucose & $5 \cdot 24 \pm 0.13(2)$ & $4.08 \pm 0.18(4)$ & $5.26 \pm 0.28(5)$ \\
\hline Sucrose & $5.54 \pm 0.06(2)$ & $5.83 \pm 0.37(4)$ & $5.58+0.54(5)$ \\
\hline Fructose & $6.49 \pm 0.04(2)$ & $5.08 \pm 0.29(3)$ & $5.92 \pm 0.45(3)$ \\
\hline Lactose & $6.44 \pm 0.02(2)$ & $6.07 \pm 0.37(2)$ & $6.47 \pm 0.62(2)$ \\
\hline
\end{tabular}

All nine bacterial populations present in the inoculum grew at $\mathrm{pH} 7 \cdot 0$. This corresponds approximately to the resting $\mathrm{pH}$ of plaque on healthy enamel surfaces (Geddes \& Jenkins, 1974). The composition and behaviour of this community was also consistent with what may be expected at healthy sites exhibiting, for example, high levels of amino acid metabolism (Table 3), a mixed pattern of fermentation products with lactate present as only a minor component (Table 4), and only small changes in $\mathrm{pH}$ resulting from the endogenous metabolism of storage material or after a sugar pulse (Table 5). When $\mathrm{pH}$ control of the chemostat was discontinued, the $\mathrm{pH}$ fell rapidly at first and then more slowly, and finally stabilized at $\mathrm{pH} 4 \cdot 1$. This was accompanied by a simultaneous rise in $E_{\mathrm{h}}$; a similar inverse relationship was reported previously in a study of films of oral micro-organisms grown in an artificial mouth (Russell \& Coulter, 1975). Surprisingly, except for $B$. intermedius, which was not detected below pH $4 \cdot 6$, all of the bacteria persisted under steady-state conditions at $\mathrm{pH} 4 \cdot 1$. This would not have been predicted from recent pure culture studies in which a number of oral bacteria including $S$. sanguis and $A$. viscosus could not grow at pH 5.0 (Harper \& Loesche, 1984). This again emphasizes the need for caution when extrapolating from pure culture studies in the laboratory to complex, mixed culture systems in vivo. Other studies, using an artificial mouth, have also shown that some bacteria, such as $A$. viscosus, are better able to survive in a complex mixed culture rather than simple mixtures of two organisms, even at low pH (Ahmed \& Russell, 1978). 
The apparent high acid tolerance of the bacteria reported here might be a consequence of the $\mathrm{pH}$ being lowered gradually by the metabolism of the bacteria themselves, thus giving an opportunity for the organisms to adapt, or it may suggest that communities of interacting bacteria can protect one another from the effects of low $\mathrm{pH}$ environments. Certainly, aggregation between cells was observed during growth at this low $\mathrm{pH}$ although the bacteriological composition of these associations was not studied. In an earlier study of oral bacteria grown in mixed continuous culture at $\mathrm{pH} 7 \cdot 0$, co-aggregation between different species in the culture vessel was common, and obligately anaerobic bacteria (fusobacteria) were seen and recovered viable from aerobically-grown colonies of Neisseria (McKee et al., 1985). In the present study, the survival of obligately anaerobic populations such as $V$. alcalescens and $F$. nucleatum during growth at $\mathrm{pH} 4.1$ implied that the loss of $B$. intermedius was due to $\mathrm{pH}$ and not to the concomitant rise in $E_{\mathrm{h}}$, although it is possible that these strains might have a differential sensitivity to $E_{\mathrm{h}}$.

Although the resting $\mathrm{pH}$ of plaque is around neutrality, the $\mathrm{pH}$ falls to below $\mathrm{pH} 5.0$ within minutes of the ingestion of dietary carbohydrates (Schachtele \& Jensen, 1982), while the $\mathrm{pH}$ at the base of a carious lesion is frequently around $4 \cdot 0$, and may be as low as $3 \cdot 2$ (Dirksen et al., 1963). In our study, when the $\mathrm{pH}$ fell to $\mathrm{pH} 4 \cdot 1$, with the exception of $L$. casei, the viable count of each species fell, although the numbers of $S$. mutans were less affected than those of other populations, particularly $S$. sanguis and $F$. nucleatum (Table 1, Fig. 1). Indeed, the proportions of $L$. case $i$ and $S$. mutans within the community increased during growth at $\mathrm{pH} 4 \cdot 1$. Similar effects have been observed in vivo in man during the progression of incipient carious lesions (for example, see Loesche \& Straffon, 1979; Marsh et al., 1980; Boyar \& Bowden, 1985), and after the regular rinsing of a low pH buffer solution (pH 3.9) around the oral cavity (Svanberg, 1980). In the latter study, the proportion of $S$. mutans fell to near its original level when use of the mouthrinse was discontinued, just as we found when $\mathrm{pH}$ control was restored to the chemostat.

Two bacterial populations that did not thrive at the lower $\mathrm{pH}$ were $F$. nucleatum and $B$. intermedius. Elevated levels of these organisms have been associated with some periodontal diseases; the $\mathrm{pH}$ of a periodontal pocket varies with its depth (Kleinberg \& Hall, 1969) but is invariably above $\mathrm{pH} 7.0$ and is commonly as high as $\mathrm{pH} 8.5$ (Bickel \& Cimasoni, 1985; Kleinberg \& Hall, 1969). Thus, $\mathrm{pH}$ may be an important factor controlling the numbers of these organisms in plaque. In contrast, $V$. alcalescens grew well and remained a predominant organism at $\mathrm{pH} 4 \cdot 1$. Veillonella cannot metabolize sugars but can form food-chains with lactate-producing bacteria (Mikx \& van der Hoeven, 1975) and, after studies with gnotobiotic animals (Mikx et al., 1972), it was proposed that these organisms might modify the carious process by converting lactic acid to weaker acids (acetic and propionic). However, the recent findings of increased levels of Veillonella at carious sites in man (Boyar \& Bowden, 1985; Milnes \& Bowden, 1985), coupled with the in vitro observations that members of this genus can stimulate the growth (McKee et al., 1983) and glycolytic activity (Hamilton \& $\mathrm{Ng}$, 1983) of $S$. mutans, suggest that the role of these bacteria in human plaque may have to be re-assessed. Certainly, the results presented here support the proposal that high levels of Veillonella might reflect environments with a high lactate concentration (Boyar \& Bowden, 1985; Milnes \& Bowden, 1985) since this was the predominant fermentation product during growth in the chemostat at pH 4.1 (Table 4). This change in pattern could not be attributed to an increase in the numbers of bacteria with a homolactic fermentation pattern. It may be due to a switch in metabolism induced by prolonged growth at low $\mathrm{pH}$ or it may simply reflect the fact that glucose was no longer apparently limiting the growth of the community (Table 2) since lactate became the major fermentation product when similar mixed cultures were grown under glucose-excess conditions at $\mathrm{pH}$ 7.0 (Marsh et al., 1983; McKee et al., 1985). The high acid tolerance of $V$. alcalescens observed here might also account for the relatively large numbers of this species found in the stomach of patients with, for example, dyspepsia (Borriello et al., 1985) or when the $\mathrm{pH}$ is raised to around $\mathrm{pH} 4 \cdot 0$ after drug treatment (Milton-Thompson et al., 1982).

A number of other changes in the metabolism of bacteria were observed during growth at low $\mathrm{pH}$ in the chemostat. Washed cells produced more acid after a pulse of glucose, fructose or lactose than did the communities cultured at neutral $\mathrm{pH}$, while amino acid metabolism was 
markedly decreased. The latter may be of great significance in plaque ecology since base production from the metabolism of salivary peptides and amino acids is considered to be important in maintaining the integrity of enamel (Kleinberg et al., 1976). When $\mathrm{pH}$ control was restored, the composition (with the exception of $B$. intermedius) and behaviour of the community rapidly reverted to that seen originally at $\mathrm{pH} 7 \cdot 0$. An inverse relationship in the proportions of $S$. sanguis and $S$. mutans was found in this study during growth at neutral and low $\mathrm{pH}$, which was similar to that observed in human plaque (de Stoppelaar et al., 1970). The findings in vivo were attributed to the availability of dietary carbohydrates. However, a consideration of the results acquired here and in a previous chemostat study (McKee et al., 1985) suggests that the inverse relationship may be more of a reflection of the $\mathrm{pH}$ in plaque resulting from the catabolism of sugars rather than of the concentration of carbohydrate per se.

In conclusion, this study has confirmed the importance of the aciduricity (acid tolerance) of bacteria in dental plaque ecology. A lowering of the $\mathrm{pH}$ of plaque would suppress the numbers of several bacterial populations found at healthy sites while increasing the proportion of bacteria associated with the development of a carious lesion. This change in flora would decrease base production from the metabolism of salivary components, increase the rate of acid production (especially lactic acid) from pulses of dietary carbohydrates, and extend the $\mathrm{pH}$ range over which glycolysis can occur. While no attempt was made here to simulate the mouth directly, the results serve to highlight the potential of the chemostat in studies of dental plaque ecology. We plan to study the effect of other dietary components and antimicrobial agents on the composition and metabolism of these defined communities.

\section{REFERENCES}

Ahmed, F. I. K. \& Russell, C. (1978). Plaque formation in vitro by Actinomyces viscosus in the presence of Streptococcus sanguis or Streptococcus mutans. Microbios 23, 93-98.

BeCKers, H. J. A. \& VAN DER HoEven, J. S. (1982). Growth rates of Actinomyces viscosus and Streptococcus mutans during early colonization of tooth surfaces in gnotobiotic rats. Infection and Immunity 35, 583587.

BiCKel, J. \& Cimasoni, G. (1985). The pH of human crevicular fluid measured by a new micro-analytical technique. Journal of Periodontal Research 20, 35-40.

Borriello, S. P., ReED, P. J., Dolby, J. M., BARCLAY, F. E. \& Webster, A. D. B. (1985). Microbial and metabolic profile of achlorhydric stomach : comparison of pernicious anaemia and hypogammaglobulinaemia. Journal of Clinical Pathology 38, 946-953.

BOYAR, R. M. \& BOWDEN, G. H. (1985). The microflora associated with the progression of incipient carious lesions in teeth of children living in a water-fluoridated area. Caries Research 19, 298-306.

Brown, C. M., Ellwood, D. C. \& Hunter, J. R. (1978). Enrichments in a chemostat. In Techniques for the Study of Mixed Populations, pp. 213-222. Edited by D. W. Lovelock \& R. Davies. London: Academic Press.

Dirksen, T. R., LitTLE, I. M. F. \& BibBy, B. G. (1963). The $\mathrm{pH}$ of carious cavities. II. The $\mathrm{pH}$ at different depths in isolated cavities. Archives of Oral Biology 8, 91-97.

GedDes, D. A. M. \& Jenkins, G. N. (1974). Intrinsic and extrinsic factors influencing the flora of the mouth. In The Normal Microbial Flora of Man, pp. 85-100. Edited by F. A. Skinner \& J. G. Carr. London: Academic Press.

Hamilton, I. R. \& NG, S. K. C. (1983). Stimulation of glycolysis through lactate consumption in a resting cell mixture of Streptococcus salivarius and Veillonella parvula. FEMS Microbiology Letters 20, 61-65.

HARPER, D. S. \& LoESCHE, W. J. (1984). Growth and acid tolerance of human dental plaque bacteria. Archives of Oral Bacteriology 29, 843-848.

VAN DER HoEven, J. S. \& DE JoNG, M. H. (1984). Continuous culture studies and their relation to the in vivo behaviour of oral bacteria. In Continuous Culture 8. Biotechnology, Medicine and the Environment, pp. 89-109. Edited by A. C. R. Dean, D. C. Ellwood \& C. G. T. Evans. Chichester: Ellis Horwood.

KLEINBERG, I. \& HaLl, G. (1969). pH and depth of gingival crevices in different areas of the mouths of fasting humans. Journal of Periodontal Research 4, 109-117.

Kleinberg, I., Kanapka, J. A. \& Craw, D. (1976). Effect of saliva and salivary factors on the metabolism of the mixed oral fiora. In Microbial Aspects of Dental Caries II, pp. 433-464. Edited by H. M. Stiles, W. J. Loesche \& T. C. O'Brien. Washington, DC: Information Retrieval.

LoEsCHE, W. J. \& STRAFFon, L. H. (1979). Longitudinal investigations of the role of Streptococcus mutans in human fissure decay. Infection and Immunity 26, 498-507.

MCKee, A. S., Marsh, P. D., Keevil, C. W. \& ElLwOOD, D. C. (1983). Interactions between Streptococcus mutans and Veillonella alcalescens grown together in a chemostat. Journal of Dental Research 62, 440.

McKee, A. S., McDermid, A. S., Ellwood, D. C. \& MARSH, P. D. (1985). The establishment of reproducible, complex communities of oral bacteria in the chemostat using defined inocula. Journal of Applied Bacteriology 59, 263-275.

MARSH, P. D. \& MARTIN, M. V. (1984). Oral Microbiology, 2nd edn, pp. 75-98. Wokingham: van Nostrand Reinhold. 
Marsh, P. D., Hardie, J. M. \& Evans, S. J. (1980). Association of Streptococcus mutans with progressive carious lesions at approximal sites in schoolchildren - preliminary findings. Caries Research 14, 158-159.

Marsh, P. D., Williamson, M. I., KeEvil, C. W., MCDermid, A. S. \& Ellwood, D. C. (1982). The influence of sodium and potassium ions on acid production by washed cells of Streptococcus mutans Ingbritt and Streptococcus sanguis NCTC 7865 grown in a chemostat. Infection and Immunity 36, 476-483.

Marsh, P. D., Hunter, J. R., Bowden, G. H., Hamilton, I. R., McKeE, A. S., HaRdie, J. M. \& ELLWOOD, D. C. (1983). The influence of growth rate and nutrient limitation on the microbial composition and biochemical properties of a mixed culture of oral bacteria grown in a chemostat. Journal of General Microbiology 129, 755-770.

Marsh, P. D., Keevil, C. W. \& Ellwood, D. C. (1984). Relationship of bioenergetic processes to the pathogenic properties of oral bacteria. Journal of Dental Research 63, 401-406.

Mikx, F. H. M. \& VAN DER HoEven, J. S. (1975). Symbiosis of Streptococcus mutans and Veillonella alcalescens in mixed continuous cultures. Archives of Oral Biology 20, 407-410.

Mikx, F. H. M., van der Hoeven, J. S., Konig, K. G., Plasschaert, A. J. M. \& Guggenheim, B. (1972). Establishment of defined microbial ecosystems in germ free rats. I. Effect of interaction of Streptococcus mutans or Streptococcus sanguis with Veillonella alcalescens on plaque formation and caries activity. Caries Research 6, 211-223.
Milnes, A. R. \& Bowden, G. H. W. (1985). The microflora associated with developing lesions of nursing caries. Caries Research 19, 289-297.

Milton-Thompson, G. J., Lightfoot, N. F., AhMet, Z., Hunt, R. H., Barnard, J., Bavin, P. M., Brimblecombe, R. W., Darkin, D. W., Moore, P. J. \& VINEY, N. (1982). Intragastric acidity, bacteria, nitrite, and $\mathrm{N}$-nitroso compounds before, during, and after cimetidine treatment. Lancet $\mathbf{i}$, 1091-1095.

Russell, C. \& Coulter, W. A. (1975). Continuous monitoring of $\mathrm{pH}$ and $\mathrm{Eh}$ in bacterial plaque grown on a tooth in an artificial mouth. Applied Microbiology 29, 141-144.

Schachtele, C. F. \& Jensen, M. E. (1982). Comparison of methods for monitoring changes in the $\mathrm{pH}$ of human plaque. Journal of Dental Research 61, 11171125.

Shah, H. N., Williams, R. A. D., Bowden, G. H. \& HaRdie, J. M. (1976). Comparison of the biochemical properties of Bacteroides melaninogenicus from human dental plaque and other sites. Journal of Applied Bacteriology 41, 473-492.

De Stoppelaar, J. D., van Houte, J. \& Backer Dirks, O. (1970). The effect of carbohydrate restriction on the presence of Streptococcus mutans, Streptococcus sanguis and iodophilic polysaccharide-producing bacteria in human dental plaque. Caries Research 4, 114-123.

SvanberG, M. (1980). Streptococcus mutans in plaque after mouth-rinsing with buffers of varying $\mathrm{pH}$ value. Scandinavian Journal of Dental Research 88, 76-78. 